\title{
Exergeoeconomic of 50 W Solar PV Module
}

\author{
Mohammad Salman Ismail* and N. L. Panwar \\ Department of Renewable Energy Engineering, Maharana Pratap University of Agriculture \\ and Technology, Udaipur, Rajasthan, India \\ *Corresponding author
}

Keywords

Solar PV, exergy, energy,

exergoeconomic performance

Article Info

Accepted:

20 May 2021

Available Online:

10 June 2021

\section{A B S T R A C T}

The objective of the present study is to determine the exergeoecomic performance of solar PV panel. The study was conducted in April(2021) under climatic conditions of Udaipur $\left(24^{\circ} 35^{\prime} 7^{\prime \prime}{ }^{\circ} \mathrm{N} ; 73^{\circ} 42^{\prime} 45^{\prime \prime}{ }^{\circ} \mathrm{E}\right)$. The Exergy output, Exergy input and Energy input, Energy output was calculated. The Energy loss and Exergy loss was determined. It was found out that exergy loss was higher as compared to energy losses. Exergy input is always higher than energy input. Due to the change in ambient temperature and module temperature exergoeconomic performance is greatly affected. Due to the inclusion of factor related to temperature difference and wind velocity, exergy output is always less than the energy output.

\section{Introduction}

In this modern and technological era, there is always high energy demands, conventional sources are depleting at an alarming rate. Fossil fuels when burned leads to the emission of harmful gases such as carbon dioxide and carbon monoxide. These gases not only pollute the environment but also lead to global warming (1-2). The Intergovernmental Panel on climate change estimated a temperature rise of 2.5 degree Celsius by the next centuries. Solar energy is a form of renewable energy that is inexhaustible. Sudhakar et al., $(3,4)$ reported that solar radiation intensity in Indian climatic conditions is varied in the range of 4$7 \mathrm{~kW} \mathrm{~h} /\left(\mathrm{m}^{2}\right.$ day $)$ annually. A solar PV system can convert solar radiation into electrical energy. Employing solar PV system enormously increase sustainability.

As per the Indian scenario, solar PV systems can meet the increasing energy demands, as India gets maximum hours of sunshine. Thus India holds immense potential in solar energy. The application of solar energy will also help in reducing pollution and the global warming effect. 
Due to such great advantages of solar PV system engineers and scientists are constantly researching to increase its efficiency and performance. The conventionally used energy analysis does not give a clear insight intothe performance assessment of solar PV system.

Thus a new method of exergetic analysis was introduced. Exergy analysis is based on the second law of thermodynamics it thus helps in quantitatively detect and evaluate the thermodynamic irreversibility in a system.

Hence it helps in thermodynamic improvement of the system. Sahin et al., (5) investigated the thermodynamic characteristics of the solar photovoltaic (PV) cells using exergy analysis. They developed and applied the new approach for the assessment of PV cells and found that the presented approach was realistic as it accounts for thermodynamic quantities such as enthalpy and entropy. Though this analysis helps in giving clear insight very few works of literature have been reported on the method.

The technique which combines scientific assessment with economic consideration to achieve optimum design is called exergoeconomics (6).

It helps in calculating of cost of inefficiencies by undertaking exergy losses and energy losses into consideration. Agrawal et al., (7) conducted exergoeconomics analysis of a glazed photovoltaic thermal module air collector. The Exergoeconomic of the various thermal systemwas discussed by M. A Dincer et al., (8).

The ratio of thermodynamic loss rate to capital cost is a significant parameter (9). Thus using this method experiment was conducted to estimate the exergy losses and economic parameters under the climatic condition of the Udaipur region.

\section{Materials and Methods}

\section{System Description}

An experimental investigation was carried out at College of technology Agriculture Engineering Udaipur (Rajasthan), India $\left(24^{\circ} 35^{\prime} 7^{\prime \prime} \mathrm{N} ; 7^{\circ} 42^{\prime} 45^{\prime \prime} \mathrm{E}\right.$ and at an altitude of $582.5 \mathrm{~m}$ above mean sea level). The study was performed during April 2021 in real atmospheric conditions. The technical specifications of solar panel are presented in Table 1.

The values of the input parameter for further analysis of the PV system are shown in Table.2.

\section{Exergoeconomic Analysis}

Exergoecomic uses exergy and energy analysis with its economics. According to the study conducted by Rosen et al., and Tiwari et al., $(10,11)$, on Exergy cost Energy mass analysis. First, all the exergy and energy analysis is performed. And energy loss rate and the exergy loss rate is calculated.

$$
\begin{aligned}
& \mathrm{En}_{\text {in }}-\mathrm{En}_{\text {out }}=\mathrm{L}_{\text {en }} \ldots(1) \\
& \mathrm{Ex}_{\text {in }}-\mathrm{Ex}_{\text {out }}=\mathrm{L}_{\text {dest }} \ldots(2)
\end{aligned}
$$

Where Enis energy, Ex is exergy. Suffix in is for input and out is for output. Len is the energy loss rate and $L_{\text {dest }}$ is the exergy destruction rate.

In this analysis, exergoeconomic parameter $\mathrm{R}$ is formed. This parameter is the ratio of the thermodynamic loss rate (L) to the net capital $\operatorname{cost}(\mathrm{K})$. The terminology 'Ren' is used to represent energetic terms whereas 'Rex' denoted exergitic parameters.

Thus, exergoeconomic parameter equation is given by. 
$\mathrm{R}=\frac{\mathrm{L}}{\mathrm{K}}$

Similarly, for energetic and exergetic considerations the parameter equation is given by.

$$
\begin{aligned}
& \mathrm{R}_{\mathrm{en}}=\frac{\mathrm{L}_{\mathrm{en}}}{\mathrm{K}} \ldots(4) \\
& \mathrm{R}_{e x}=\frac{\mathrm{L}_{\text {dest }}}{\mathrm{K}} \ldots(5)
\end{aligned}
$$

\section{Energy Loss Rate}

In order to find the input and output energy of the PV module, the above parameters and values are calculated by instruments such as luxmeter for calculating solar radiation.

And wire wound rheostat of $50 \Omega$, to calculate the current and voltage in load condition is used. The current-voltage data is read by the multimeters. The energy loss rate is a difference between energy input and energy output. Thus it's given by(12).

The energy input of the module is the product of solar radiation (Is) $\mathrm{W} / \mathrm{m}^{2}$ and effective area (A) $\mathrm{m}^{2}$.

$$
\mathrm{En}_{\mathrm{in}}=\mathrm{Is} \times \mathrm{A} \ldots(6)
$$

The energy output is power generated by the PV module in load condition.

$\mathrm{En}_{\text {out }}=\mathrm{Vm} \times \mathrm{Im}$

Thus from equation (6) and (7)

$$
\mathrm{L}_{\mathrm{en}}=\mathrm{IsA}-\mathrm{VmIm}
$$

Using the above equation exergeoeconomic parameter considering energetics of the system (Ren) is calculated.

\section{Exergy Loss Rate}

To find the exergy loss rate, exergy input and output is calculated by the equation given by (13) for electrical exergy and thermal exergy. Similarly, the exergy loss rate is a difference between exergy input and exergy output.

The Input exergy is calculated by the following equation

$$
\mathrm{Ex}_{\mathrm{in}}=\operatorname{Is} \times \mathrm{A}\left(1-\frac{\mathrm{Ta}}{\mathrm{Ts}}\right)
$$

Where $\mathrm{Ts}$ is taken as $5777 \mathrm{~K}$ as per Holmberg's study (14).

The output exergy is the difference between electrical exergy and thermal exergy which can be calculated as per the equation given below.

$\mathrm{Ex}_{\text {elec }}=\mathrm{VmIm} \ldots(10)$

$\mathrm{Ex}_{\text {therm }}=\left(1-\frac{\mathrm{Ta}}{\text { Tcell }}\right) \mathrm{hcA}($ Tcell $-\mathrm{Ta})$

$\mathrm{hc}=5.7+3.8 \mathrm{v} \ldots(12)$

Where $\mathrm{v}$ is wind velocity in $\mathrm{m} / \mathrm{sec}$. As per the above equation, the exergy destruction rate is calculated using Eq (9) and (12)

$\mathrm{L}_{\text {des }}=\operatorname{VmIm}-\left(1-\frac{\mathrm{T}_{\mathrm{a}}}{\mathrm{T}_{\text {cell }}}\right) \mathrm{hcA}\left(\mathrm{T}_{\text {cell }}-\mathrm{T}_{\mathrm{a}}\right)$

The exergoeconomic parameter $\mathrm{R}_{\mathrm{ex}}$ can be calculated considering the exergetic aspect of the system.

\section{Results and Discussion}

Exergy loss rate, Energy loss rate and exergoeconomic parameters

Exergoeconomic analysis has been performed in April. To obtain better changes four 
consecutive days have been selected and result analysis has been illustrated in the following figures. According to the figure, there is a parallel variation between energy loss rate and exergy loss rate

Going further into details energy loss rate varies from $79.3 \mathrm{~W}$ to $289 \mathrm{~W}$. And the exergy loss rate varies from $83.7 \mathrm{~W}$ to $312 \mathrm{~W}$, with an average efficiency of the module $12.3 \%$. The relative difference exergoeconomic parameters $R_{\mathrm{en}}$ varies from 0.0023 to 0.0053 . Among the $\mathrm{R}_{\mathrm{ex}}$ values of selected days 0.0026 $\mathrm{W} / \mathrm{Rs}$, was the minimum value and 0.006 $\mathrm{W} / \mathrm{Rs}$ as the maximum value. Also depending upon the $\mathrm{L}_{\mathrm{en}}$ and $\mathrm{L}_{\mathrm{des}}, \mathrm{R}$ values decrease during the afternoon and increase during the morning and evening period. The result obtained was similar as reported by Bayat et al., (16).

As mentioned earlier solar irradiation have a linear relation with the $\mathrm{L}_{\mathrm{en}}, \mathrm{L}_{\text {dest }}$. Thus it can be seen in Fig(a) and Fig(b), the graph reaches peak at 1:00 pm. The values of $R_{\mathrm{ex}}$ and $\mathrm{R}_{\mathrm{en}}$ were maximum during the morning and evening economically this means losses are more valuable during this time rather during the day. $R_{e x}$ and $R_{e n}$ have also shown a lower linear behavior with the solar irradiation.

Table.1 Specification of PV system

\begin{tabular}{|c|c|}
\hline Parameter & Values \\
\hline Model No. & GOLDI050PM \\
\hline Rated Power (Pmax) & $50 \mathrm{~W}$ \\
\hline Open Circuit Voltage (Voc) & $21.5 \mathrm{~V}$ \\
\hline Short Circuit Current(Isc) & $3.14 \mathrm{~A}$ \\
\hline Voltage at Maximum & $17.7 \mathrm{~V}$ \\
Power(Vm) & $2.85 \mathrm{~A}$ \\
Current at Maximum & $1000 \mathrm{~V}$ \\
Power(Im) & \\
Maximum System Voltage & \\
\hline
\end{tabular}

Table.2 Input parameters used in research work

\begin{tabular}{|c|c|}
\hline Input Parameters & Values \\
\hline $\begin{array}{c}\text { Ambient Temperature } \\
\text { (Ta) }\end{array}$ & $308 \pm 5 \mathrm{~K}$ \\
\hline $\begin{array}{c}\text { Temperature of the Sun } \\
\text { (Ts) }\end{array}$ & $5777 \mathrm{~K}$ \\
\hline Cell Temperature (Tcell) & $320 \pm 10 \mathrm{~K}$ \\
\hline Effective Area (A) & $0.36 \mathrm{~m}^{2}$ \\
\hline Fill Factor & 0.85 \\
\hline
\end{tabular}


Fig.a Energy Loss rate on selected days

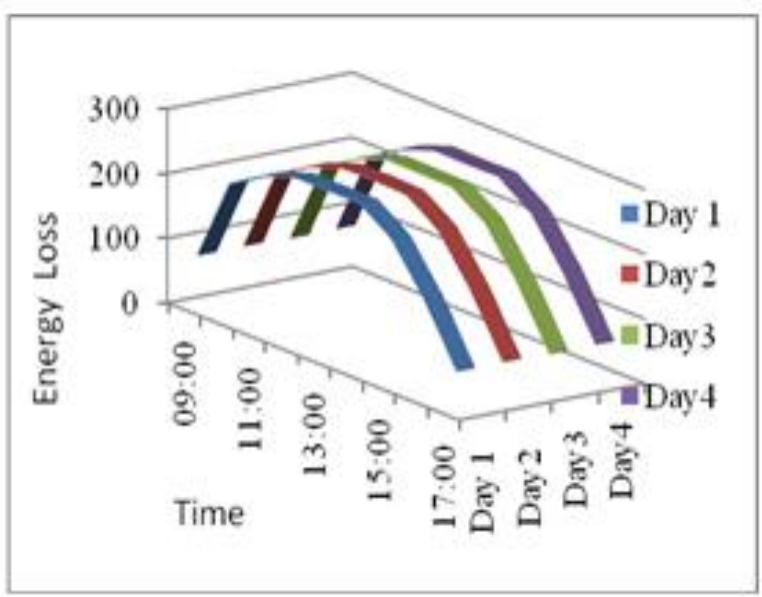

Fig.c Variation in R on 12 April

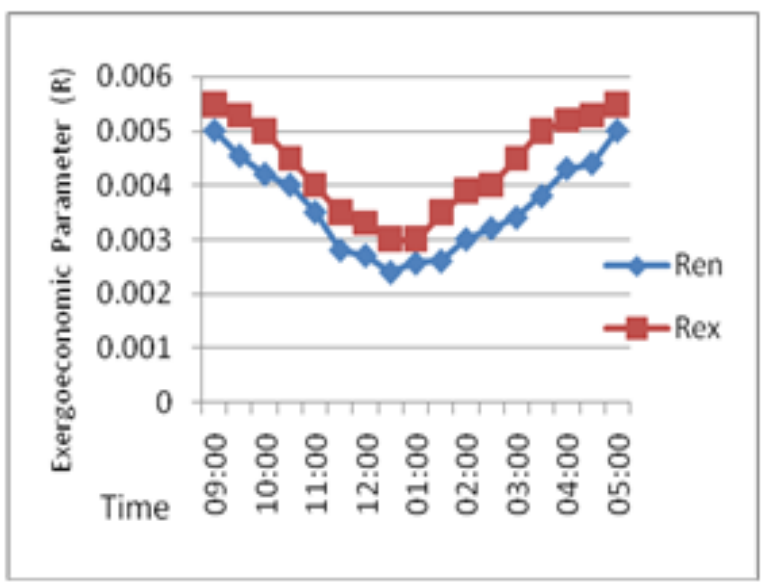

Fig.e Variation in R on 20 April

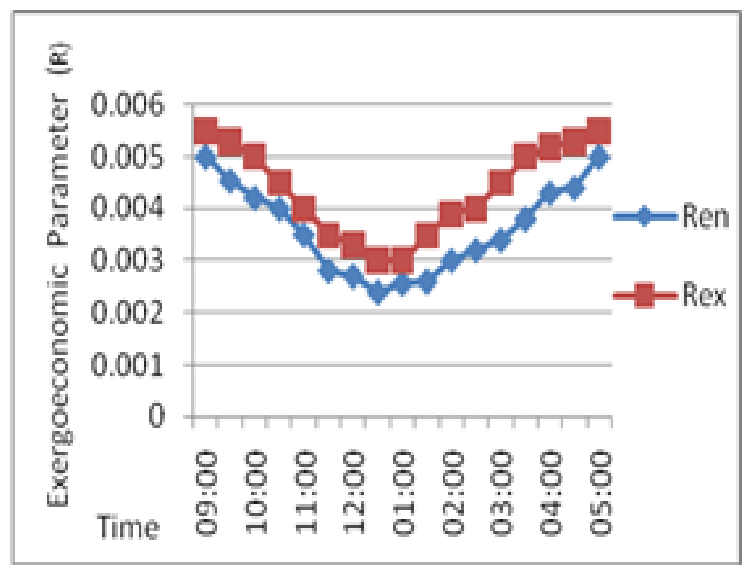

Fig.b Exergy Loss rate on selected days

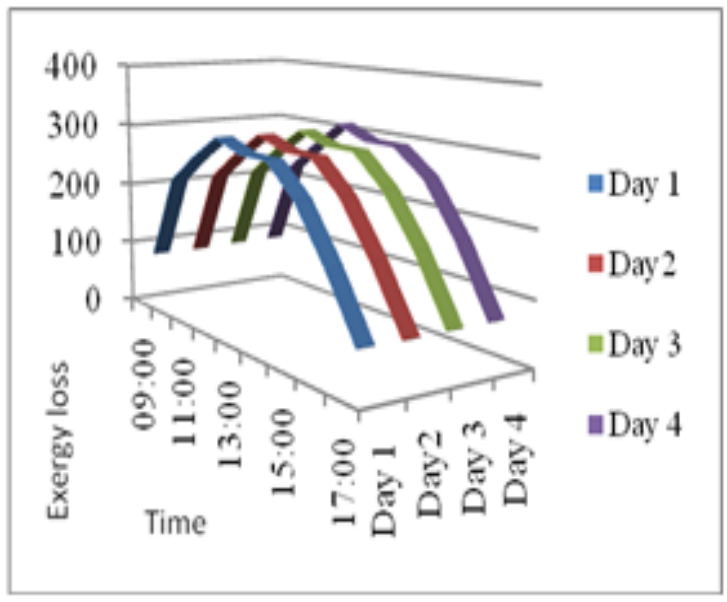

Fig.d Variation in R on 16 April

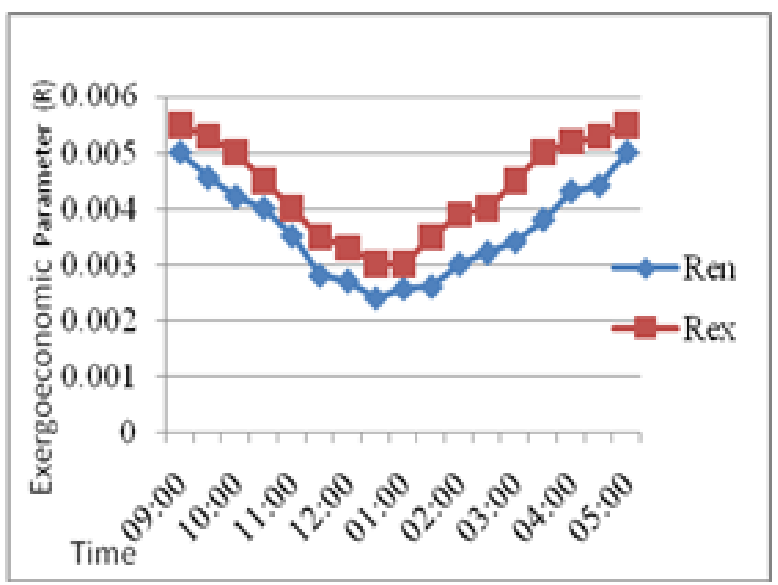

Fig.f Variation in R on 24 April

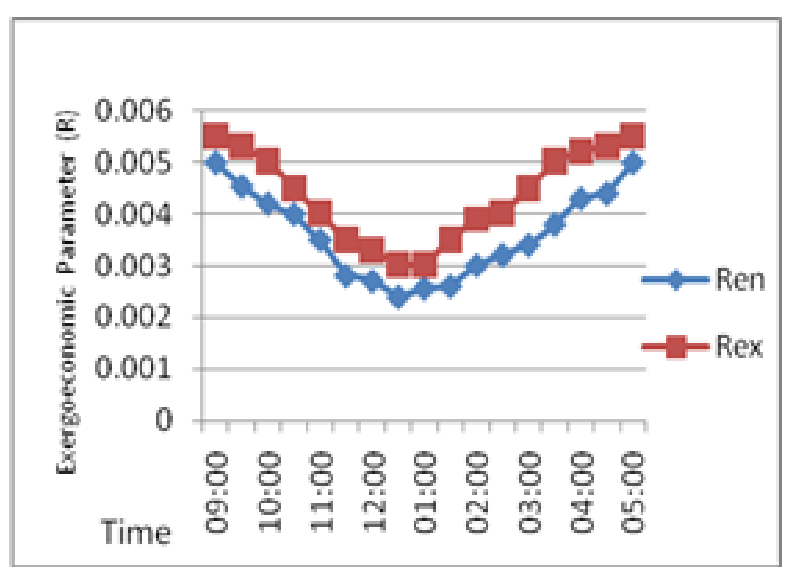


Figure $a$ and $b$ shows the variation in energy and exergy loss with time respectively. The change in exergoeconomic parameter(R) with time is shown in Figure $\mathrm{c}$ to $\mathrm{f}$.

In this paper exergoeconomic parameters of energy and exergy efficiencies for $50 \mathrm{~W}$ solar modules were investigated in May. According to the investigation it was found out that $R_{e x}$ is always greater than $R_{\mathrm{en}}$. It was also observed that exergy losses are more than energy losses. As PV modules are electrical devices thus ambient temperature play an important role inthe overall performance of the system. It has been observed that ambient temperature has a negative effect on the system. Also, $\mathrm{R}_{\mathrm{ex}}$ is a key parameter for device feasibility; the appropriate value of $R_{\mathrm{ex}}$ can be used as a design parameter for cost-effective and highperformance devices. Wind velocity impact on losses was found to be very less significant in the month April.

\section{References}

1. Panwar, N. L., Kaushik, S. C., and Kothari, S., Renewable Sustainable Energy Rev., 2011, vol. 15, pp. 15131524.

2. Panwar, N. L. and Jadhav, S. S., 2018. Energetic and Exergetic Assessment of 50 W Solar PV System. Applied Solar Energy, 54(5), pp.303-307.

3. Sudhakar, K., Rajesh, M. and Premalatha, M., 2012. A mathematical model to assess the potential of algal bio-fuels in India. Energy Sources, Part A: Recovery, Utilization, and Environmental Effects, 34(12), pp.1114-1120.

4. Sudhakar, K. and Srivastava, T., Int. J. Ambient Energy,2014, vol. 35, no. 1, pp. 51-57.

5. Sahin, A. D., Dincer, I. and Rosen, M. A., 2007. Thermodynamic analysis of solar photovoltaic cell systems. Solar energy materials and solar cells, 91(2-3), pp.153-
159.

6. R. Rayegan, "Exergoeconomic Analysis of Solar Organic Rankine Cycle for Geothermal Air Conditioned Net Zero Energy Buildings," 2011.

7. Agrawal, S. and Tiwari, G. N., 2012. Exergoeconomic analysis of glazed hybrid photovoltaic thermal module air.

8. Dincer, M. A., I., Rosen, Exergy: energy, environment \& sustainable development. Elsevier science and technology., 2007.

9. Tripathi, R., Tiwari, G. N. and Dwivedi, V. K., 2017. Energy matrices evaluation and exergoeconomic analysis of series connected $\mathrm{N}$ partially covered (glass to glass PV module) concentratedphotovoltaic thermal collector: At constant flow rate mode. Energy Conversion and Management, 145, pp.353-370.

10. Rosen, M. A. and I. Dincer, "Exergycost-energy-mass analysis of thermal systems and processes," Energy Convers. Manag., vol. 44, no. 10, pp. 1633-1651, 2003.

11. Tiwari, S. and Tiwari, G. N., 2016. Exergoeconomic analysis of photovoltaicthermal (PVT) mixed mode greenhouse solar dryer. Energy, 114, pp.155-164.

12. Gaur, A. and Tiwari, G. N., 2014. Exergoeconomic and enviroeconomic analysis of photovoltaic modules of different solar cells. Journal of Solar Energy, 2014, pp.1-8.

13. Izgi, E. and Akkaya, Y. E., 2013. Exergoeconomic analysis of a solar photovoltaic system in Istanbul, Turkey. Turkish Journal of Electrical Engineering \& Computer Sciences, 21(2), pp.350-359.

14. Joshi, "Thermodynamic assessment of photovoltaic systems," Sol. Energy, vol. 83, no. 1139-1149, pp. 1-7, 2009.

15. Holmberg, J., Flynn, C. and Portinari, L., 2006. The colours of the Sun. Monthly Notices of the Royal Astronomical 
Society, 367(2), pp.449-453.

16. Bayat, M., 2016, November. Exergoeconomic Analysis of a Solar Photovoltaic Module in Karabük, Turkey.
In 4th International Symposium on Innovative Technologies in Engineering and Science (ISITES2016) 3-5 Nov 2016 Alanya/Antalya-Turkey.

\section{How to cite this article:}

Mohammad Salman Ismail and Panwar, N. L. 2021. Exergeoeconomic of $50 \mathrm{~W}$ Solar PV Module. Int.J.Curr.Microbiol.App.Sci. 10(06): 548-554.

doi: https://doi.org/10.20546/ijcmas.2021.1006.060 